\title{
Factor Analysis - Dominant Factors Affecting the Investment of Natural Resources in Papua Province
}

\author{
Zainal Arifin Wasaraka \\ Universitas Cenderawasih, Indonesia \\ zariwa14@gmail.com
}

\begin{abstract}
The aims of this research are to determine and to analyze about the effect of infrastructure, bureaucracy and regulation, and culture social environment toward natural resources in Papua Provincial. The research methods are survey and path way analyses. Results from the research showed that are: 1) bureaucracy and regulation factor have direct effect to invest, it is also indirect effect with culture intervening variables, 2)The Direct effect of culture social environment to invest natural resources is $21,3 \%$.
\end{abstract}

Keywords: Dominant factors, investment, natural resources

\section{Introduction}

Natural resources such as water, air, land, oil, fish, forests and others are essential resources for human survival. The loss or reduction in the availability of these resources will extremely influence the human survival on earth. Without air and water, for example, human beings cannot live. Similarly, other natural resources such as forests, fish and so forth which are the resources that not only fulfill the human needs, but also provide a considerable contribution to the wealth of the nation. Good natural resources management will improve the people welfare, but the natural resources management which is not good will give bad impacts for human. Therefore, the fundamental problems of natural resources management is how to manage these resources in order to produce maximum benefits for humans without compromising the sustainability of natural resources itself (Fauzi, 2006). Related to the use of natural resources. Indonesia adheres to sustainable development policy that allows the conversion of natural resources into various forms of capital as an essential and integrated part of the development process (Syaukat, 2007). One of the advantages of Indonesia, it has a large number of markets (due to the large number of people and material which is rely on natural resources). It is the factor which causes foreign investors still considers Indonesia as a worthy place of investment. The specific sectors such as mining, in the work contract also needs to be included the technology transfer as a condition of allowing foreign investors to explore (operatorship). This aspect must be taken by the government so that the presence of foreign investors will not become a disaster for Indonesia's economy in the future (Yustika, 2007).

Until the beginning of 2008, there are two issues that still surround the economic conditions in Indonesia, the high poverty and declining investment that cannot be separated from unemployment. It is certainly interesting to be observed when the government's efforts give a facility for investment; it does not apparently give a significance meaning. It is mainly through several government regulations such as Regulation No. $76 / 2007$ and No. 77/2007 which is expected to become a magnet for investors as a legal certainty for investment in Indonesia. Until the end of 2007, foreign investment was only USD 8.9 billion, while domestic investment Rp. 44.6 trillion. This certainly begs the question, is Indonesia not interesting for the investors? (Suman in Cepos, February 13, 2008). The capital market analyst, Edwin Sinaga, assess that there are several promising sectors in 2008, mining, energy, plantations, and banking. He suspects the investment manager or large investors will be looking for stocks in this sector to break down its investment portfolio, the four sectors were indeed booming. Over the past year, the industry average growing quite rapidly. Production increases, demand is high and the price on the international market surged, it is becoming the industry are very prospective. Moreover, the three sectors of mining, energy and plantations provide income in US dollars. So as soaring prices in the world market, also raised the issuer-emitan sector so the choice is stocks or issuers whose fundamentals and good liquidity transaction (the Economic News, 2007; 62). 
Papua has a resource with agriculture potential based, large of forestry and marine. The efforts to improve the productivity of the primary sector through the agriculture industrialization is the right way, it will give the impact on the transformation of resources with higher additional value. The agricultural industrialization development problems in Papua are relatively small investment in agricultural sector compared to other sectors such as mining investment. The small investment in the agricultural sector in Papua happens because of lack of information concerning on the market, employment, convenient bureaucracy, raw materials availability, facilities to support the processing industry, and others that can attract investors to invest in Papua (Karma, 2005). Many factors causes the cost of investment in the province to be very expensive, according to Asmuruf (2001): (1) the condition of the infrastructure is still very limited, (2) the location of Papua is far from the market, both the national and export markets, (3) lack of an educated workforce and ready to work, and (4) there is still a long bureaucratic obstacles from some technical agencies. Besides, it is still confronted with cultural effects, the political situation and security problems in some places. Referring to the reasons above, the research on factor analysis - dominant factors affecting the natural resources investment in Papua conducted. Based on this consideration, the research is conducted with the objective to measure and analyze the effect of bureaucracy and regulation, infrastructure availability, and culture toward the investors' interest to invest resources in Papua.

\section{Methodology}

Population and sample in this research are 30 active entrepreneurs who manage the natural resources of Papua, which consists of, 4 entrepreneurs of mineral water resources management, 8 entrepreneurs of forestry resources, 8 entrepreneurs of mine resources, 6 entrepreneurs of plantation resources, 1 fishery entrepreneur and 1 husbandry entrepreneur. Because of the population is small so that finally sampling was not done. The entire population of investors who engaged in natural resource investments can be affordable, so this research does not need specific sampling techniques. In other words, the respondents were used as the object of the research is all the investors (population). Techniques used in the data collection are the direct observation to the object, and literature review or literature research. Observations carried out by distributing questionnaires in a closed and open to the respondents. While the literature review will be reviewed various references and relevant literature to sharpen insight to view, analyze and answer the problems proposed. Basically this research is causality study using path analysis. Path analysis method chosen for this study seeks to find a causal relationship between the variables that possibly occur, as well as to discover the magnitude of the direct and indirect effect of a variable to others. In addition, all variables can be measured, so there is no latent variables (variables that cannot be measured), then the path analysis models is the most appropriate choice if want a simple model that is full meaning full. There are four variables that are subjected to experiments in this research which consists of two exogenous variables, bureaucracy and regulation variables, as well as infrastructure variable. And two endogenous variables, the cultural and investment.

\section{Findings and Discussion}

The next sub-structure equations that need to be tested its significance is equation invest sub-structure involving bureaucracy and regulation, culture, and the infrastructure independent variables, see Figure 1. Based on the processing data using SPSS 14 software the research gains the results are as follow:

Figure 1: Investment Equation Sub-structure Line Diagram

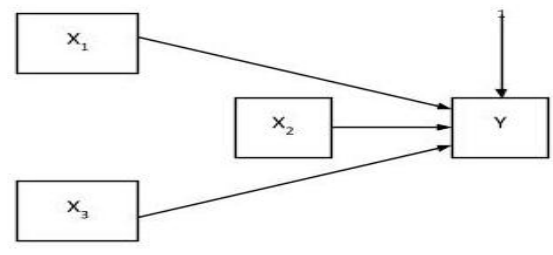


Based on the results of the above statistics, it is clearly seen that bureaucracy, regulatory, culture and infrastructure factors have a significant direct effect on investment in the level of confidence by $90 \%$. As the indicator, it can be seen in the magnitude of the coefficient $t$-stat for X2 (culture) which is equal to 2,217> t0.10 $(26)=1.3149$ so it was decided to reject $\mathrm{H}_{0}$ and accept $\mathrm{H}_{1}$, it means partially acceptable that cultural factor has a positive effect on the investors' interest to invest in Papua. Based on the coefficient track by 0.462 shows that the contribution of cultural factor towards investors' interest changes to invest is $0.2134 \%$ or 21:34. Then for infrastructure variable, based on the data processing, $t$-stat $=1,698>t_{0.10(26)}=1.3149$, it means that $\mathrm{H}_{0}$ is rejected and $\mathrm{H}_{1}$ is accepted. Thus it is partially acceptable that the infrastructure variable has a positive effect on the investors' interest to invest. In this case the contribution of the infrastructure factor to change the investors' interest to invest is 0.045 or $4.5 \%$. The last is bureaucracy and regulation variable, based on the results of data processing, it shows that the $\mathrm{t}$-stat $=1,698>\mathrm{t} 0.10(26)=1.3149$, it means that $\mathrm{H}_{0}$ is rejected and $\mathrm{H}_{1}$ is accepted. Thus it is partially acceptable that the infrastructure variable has a positive effect on the investors' interest to invest, based on coefficient figures the track can be indicated that the contribution of the bureaucratic and regulation factors toward investors' interest changes to invest only 0.083 or $8.3 \%$.

Table 1: Unstandardized regression models and the Standardized Factors Affecting Investment

\begin{tabular}{|c|c|c|c|c|c|}
\hline \multirow{2}{*}{ Model } & \multicolumn{2}{|c|}{$\begin{array}{l}\text { Unstandardized } \\
\text { Coefficients }\end{array}$} & \multirow{2}{*}{$\begin{array}{l}\text { Standardized } \\
\text { Coefficients } \\
\text { Beta }\end{array}$} & \multirow{2}{*}{$\mathbf{t}$} & \multirow[t]{2}{*}{ Sig. } \\
\hline & B & Std. Error & & & \\
\hline (Constant) & 2.960 & 4.289 & & .690 & .496 \\
\hline $\begin{array}{l}\text { Bureaucrac } \\
\text { y (X1) }\end{array}$ & .343 & .245 & .289 & 1.398 & .174 \\
\hline Culture (X2) & .430 & .194 & .462 & 2.217 & .036 \\
\hline $\begin{array}{l}\text { Infrastructu } \\
\text { re (X3) }\end{array}$ & .204 & .120 & .212 & 1.698 & .101 \\
\hline
\end{tabular}

Simultaneously, the three independent variables included in the model is used in order to explain the interest to invest is very significant at $90 \%$ in confidence level, as indicated by the value of $\mathrm{F}$-stat $=13.33>\mathrm{F}_{0.10(4 ; 26)}=$ 2.1745. Thus it can be accepted that the bureaucracy and regulation factors, culture and infrastructure factors simultaneously have a positive effect on the investors' interest to invest. The contribution of these three variables, variation changes on the investors' interest to invest is $\mathrm{R}^{2}=0.606$, or approximately $60.60 \%$, while the remaining $39.40 \%$ is due to other factors that are not included in the model.

Direct and Indirect Effect, Total of Bureaucracy, Culture and Infrastructure Factors toward Investment: One of the most important analyses reported in the path analysis model is direct and indirect effect and total of some exogenous variables toward endogenous variables. Through this analysis, it can be known or determined which factors most large or dominant effect changes of endogenous variables. In order to answer this question we need a complete structural line diagram in accordance with the number of variables analyzed. In this case, the path diagram can be seen in Figure 2. It has been statistically tested before that all the parameter coefficients included in the structural equation model is significant at the 90 confidence level, so that each parameter coefficient is statistically relevant to be analyzed. 
Figure 2: Bureaucracy, Culture and Infrastructure Line Diagram toward Investment

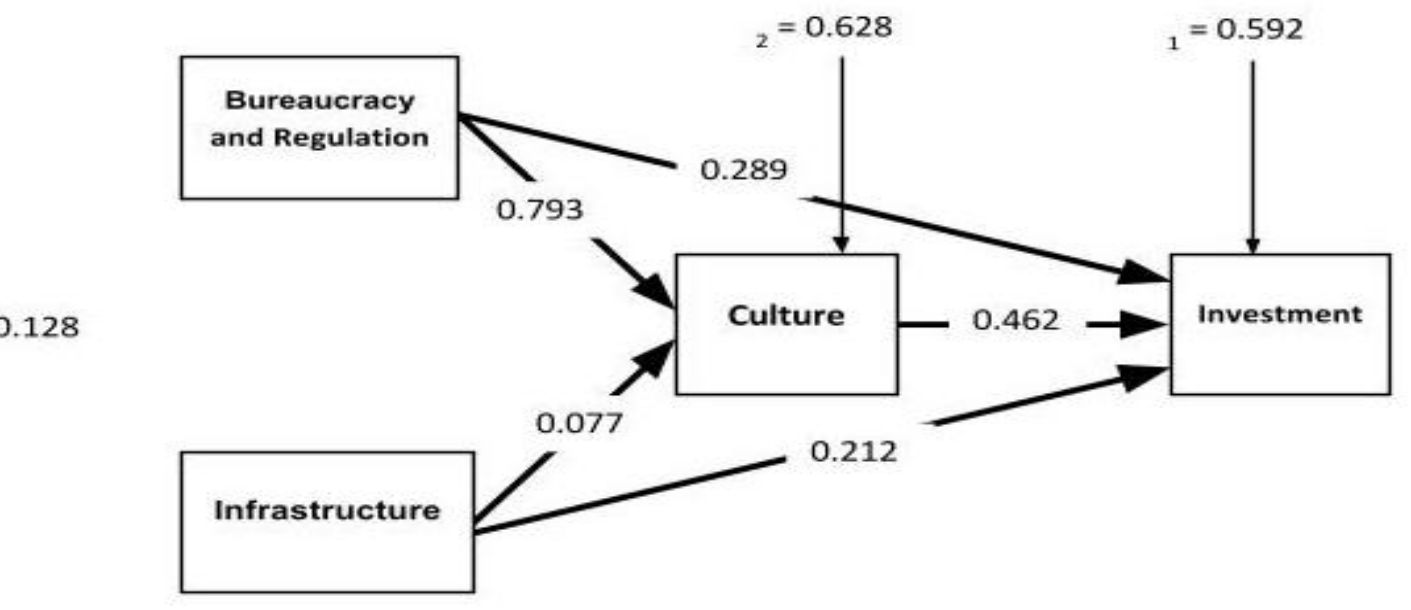

In the path diagram presented in Figure 3, it clearly seems that factors of bureaucracy and infrastructure have direct effect on investment, also have an indirect effect through cultural factor. While the culture seems to only have a direct effect on investment. Thus we can determine effect total of each determinants toward the changes to invest as follows.

The Effect of Bureaucracy and Regulation Factors toward Investment

Direct Effect

$$
\begin{array}{ll}
\text { Direct Effect } & =0.289 \times 0.289 \\
& =0.084 \\
\text { Indirect Effect through Culture } & =0.289 \times 0.792 \times 0.462 \\
& =0.105 \\
\text { Total Effect } & =0.084+0.105 \\
& =0.185
\end{array}
$$$$
\text { Total Effect } \quad=0.084+0.105
$$

It means that the variation of the change of the investors' interest to invest in the field of natural resources in Papua about 0185 or $18.5 \%$ due to the variation of the changes in bureaucracy and regulation, which consists of its direct effects by $8.4 \%$ and the effect of indirect through cultural factor about $10.5 \%$.

The Effect of Infrastructure Factor towards Investment

$$
\begin{array}{ll}
\text { Direct Effect } \quad=0.212 \times & 0.212 \\
& =0.045 \\
& =0.212 \times 0.077 \times 0.462 \\
\text { Indirect Effect through Culture } & =0.008 \\
\text { Total Effect } & =0.045+0.008 \\
& =0.053
\end{array}
$$

Based on the total effect above can be said that the variation of the change of the investors' interest to invest in the field of natural resources in Papua about 0.053 or $5.30 \%$ due to the variation of changes in the availability of infrastructure, where its effect is distributed to the direct effect of $4.5 \%$ and the indirect effect through cultural factors of $0.8 \%$.

\section{The Effect of Culture Factor towards Investment}

$\begin{array}{ll}\text { Direct Effect } & =0.462 \times 0.462 \\ & =0.213 \\ \text { Indirect Effect through Culture } & =0 \\ \text { Total Effect } & =0.213+0 \\ & =0.213\end{array}$


Thus, it can be said that the variation of change of investors' interest to invest in the field of natural resources in Papua about 0.213 or $21.3 \%$ due to the variation of cultural change of Papuan. The results of calculations above present in Table 2. If the bureaucracy and regulation factors are viewed directly, they only turn its effect on the investors' interest to invest in Papua is only 8:35\%. However, if the effect is added to indirect effect through an intervening variable culture, the total effect on the investors' interest to invest in Papua become bigger, $18.94 \%$. The meaning of these findings indicates that the investors in Papua require a very large government role as a mediator in resolving the conflict between the investor as the investment with the culture or customs of local people as owners of customary rights.

Table 2: Direct and Indirect Effect Analysis, and Total of Factors of Bureaucracy, Culture and Infrastructure toward Willingness of Investors to Invest in Papua

\begin{tabular}{llllll}
\hline No & Variable & Direct Effect & $\begin{array}{l}\text { Indirect } \\
\text { through Culture }\end{array}$ & $\begin{array}{c}\text { Tofal } \\
\text { Effect }\end{array}$ \\
\hline 1. & Bureaucracy & and & 0.0835 & 0.1059 & 0.1894 \\
& Regulation & & & & \\
2. & Culture & 0.2134 & - & 0.2134 \\
3. & Infrastructure & 0.0449 & 0.0078 & 0.0602 \\
\hline
\end{tabular}

The direct effect is smaller than the indirect effect, it can be seen above, i.e. $0084<0106$, it also shows that the investor in Papua does not too questioned the implementation of bureaucracy and regulation than the government's role to mediate the conflicts between local culture with investor. For infrastructure, according to investor perceptions, the effect is very small compared to the cultural factors. In Table 6 , the contribution on investor interest changes only 6:02\%. Investors assume that cultural factors create a conducive climate for investment in Papua, so that the handling infrastructure availability can be helped by the investor. From the analysis, it discovers that the infrastructure directly affect investment in Papua, but keep in mind that in fact the big investors such as PT. Freeport and BP Berau/Tangguh is not too big for them to build the infrastructure to support its investment in Papua. But for the smaller companies such as PT. Sinar Indah Persada which invests in mining nickel and PT. Herison that investing in wood and $r$ other small investors who are invest in the field of Natural Resources, are highly dependent on the infrastructure to support their activities, because they are still dependent on the government to prepare the infrastructures to support their business, such as roads, clean water, electricity, and so forth.

\section{Conclusion}

- The path analysis finds that the bureaucracy and regulation factors not only have the direct impacts on investors interest to invest, they also have the indirect impact through culture intervening variables. The indirect impacts are seen greater than the direct effect, respectively by $10.5 \%$ and $8.4 \%$, the total effect is $18.5 \%$.

- There is a tendency that the cultural phenomenon more appropriately used as an intervening variable in explaining the factors that affect natural resource investment in Papua, therefore the cultural factors which are indicated in the path analysis model only has a direct effect on the investors interest to invest the natural resources in Papua, 21.3\%.

- Among all the variables included in the model, the infrastructure factor has smallest total effect on investors' interest to invest in Papua only 5:30\%, consisting of a direct effect of $4.5 \%$ and the indirect effects through cultural factor of $0.8 \%$. 


\section{References}

Asmuruf, D. (2001). Upaya Peningkatan Investasi di Propinsi Irian Jaya. Makalah untuk kegiatan rapat pendahulaun raker II APPSI. APPSI, Bandung.

Fauzi, A. (2006). Ekonomi Sumber Daya Alam dan Lingkungan, teori dan aplikasi. PT. Gramedia, Jakarta.

Karma, C. (2005). Pengembangan Ekonomi Kerakyatan di Papua, Laporan Hasil Turdes, Jayapura.

Syaukat, Y. (2007). Ekonomi Sumberdaya \& Lingkungan. DES \& L-IPB, Bogor.

Suman, A. (2008). Fantasi Investasi di Indonesia, Opini dalam Cepos tanggal 13 February 2008.

Warta Ekonomi. (2007). Perspektif Baru Bisnis \& Ekonomi :Investasi, hal 62, volume 25, tahun XIX , tanggal 10 December 2007.

Yustika, A. E. (2007). Perekonomian Indonesia, Suatu Dekade Pascakrisis Ekonomi. BPFE-UNIBRAUW, Malang. 